\title{
Inovasi Pelayanan Publik Bidang Kesehatan Berbasis Home Care Di Kota Makassar
}

\author{
Arjuna Putra ${ }^{1}$, Jaelan Usman $^{2}$, Abdi $^{3}$ \\ ${ }^{1)}$ Program Studi Ilmu Administrasi Negara Unismuh Makassar \\ ${ }^{2)}$ Program Studi Ilmu Administrasi Negara Unismuh Makassar \\ ${ }^{3)}$ Program Studi IImu Administrasi Negara Unismuh Makassar
}

\begin{abstract}
This research aims to find out the implementation of Home Care innovation, it some factors that influence home care, and public services are received by society. The type of this research is Qualitative Research byusing 6 informants. The data collection techniques are observation, interview, and documentation. Result of this research presents in implementation of home care has been well with many superiorities. While, there are difficulties although home care innovation has been implemented and it can bee seen by the society in practice. The implementation of home care innovation in Makassar are influenced by the presence of Human Resources, Infrastructures, and frequency of socialization by managing of Home Care.
\end{abstract}

Keywords: Innovation, Public Service, Home Care

\begin{abstract}
ABSTRAK
Penelitian ini bertujuan untuk mengetahui pelaksanaan inovasi home care, faktor-faktor yang mempengaruhi pelaksanaan home care serta pelayanan publik yang diterima oleh masyarakat. Tipe penelitan yang digunakan adalah penelitian kualitatif dengan informan sebanyak 6 orang.Teknik pengumpulan data yang digunakan adalah observasi, wawancara dan dokumentasi. Hasil penelitian ini menunjukkan bahwa secara pelaksaanan home care telah terlaksana dengan baik dengan berbagai keunggulan yang bervariasi. Adapun tingkat kesulitannya walaupun inovasi home care terlaksana dan dapat dilihat secara nyata oleh masyarakat dalam praktik inovasi tersebut. Pelaksanaan inovasi home care di Kota Makassar dipengaruhi oleh adanya sumber daya manusia, sarana dan prasarana yang memadai, dan sosialisasi yang sudah sering dilakukan oleh pelaksana home care.
\end{abstract}

Kata kunci: Inovasi, Pelayanan Publik, Home Care 


\section{PENDAHULUAN}

Pelayanan di bidang kesehatan merupakan salah satu bentuk pelayanan yang paling banyak dibutuhkan oleh masyarakat. Ini tak lepas dari kebutuhan warga negara untuk tetap hidup sehat. Pelayanan kesehatan yang memadai merupakan tumpuan masyarakat dan menjadi salah satu kebutuhan mendasar selain pangan dan juga pendidikan.

Masyarakat berharap untuk mendapatkan penyelenggaraan pelayanan kesehatan dilaksanakan secara bertanggung jawab, aman bermutu serta merata dan non diskriminatif, sehingga hak-hak pasien sebagai penerima pelayanan kesehatan tersebut dapat terlindungi.

Pemerintah mengembangkan infrastruktur diberbagai tanah air untuk melaksanakan kewajiban melindungi masyarakat dari gangguan kesehatan. Selain itu perkembangan tersebut telah berhasil meningkatkan pelayanan kesehatan secara lebih merata.

Perkembangan era globalisasi yang menyebabkan keperawatan di harus menyesuaikan dengan perkembangan keperawatan di negara maju dari segi sosial ekonomi masyarakat semakin meningkat sehingga masyarakat menuntut pelayanan kesehatan yang berkualitas tinggi, tapi di lain pihak bagi masyarakat ekonomi menengah ke bawah mereka ingin pelayanan kesehatan yang murah dan terjangkau. Sehingga diperlukan perawatan yang meminimalkan biaya perawatan bagi masyarakat ekonomi rendah.

Semakin mahal, kurangnya layanan akses pelayanan kesehatan, sarana dan prasarana yang kurang memadai dan masalah lainnya.Masalah pelayanan kesehatan yang tentunya masih buruk akan memberikan suatu dampak yang buruk bagi masyarakat yang sudah merupakan hak setiap warga negara untuk memperoleh pelayanan kesehatan yang baik. Timbulnya sikap diskriminatif terhadap pasien yang lebih mengutamakan yang memiliki biaya yang cukup daripada masyarakat yang kurang memiliki biaya sehingga muncul istilah "orang miskin dilarang sakit". Selain itu banyaknya pasien 
yang terlantar menunjukkan potret pelayanan kesehatan yang buruk.

Program home care ini tidak memandang status warga siapa pun warga masyarakat yang menghubungi call center home care puskesmas terdekat dari rumahnya akan didatangi tim medis reaksi cepat sesuai dengan kondisi penyakit warga. Tim medis datang ke rumah warga terdiri dari perawat, dokter atau bidan tergantung kebutuhan pasien dengan menggunakan mobil ambulance mini yang dilengkapi peralatan dan obatobat standar. Setelah itu dokter akan memeriksa kondisi pasien untuk mementukan tindak lanjut perawatan pasien, untuk dirawat di puskesmas atau rumah sakit. Jika tidak membutuhkan perawatan serius, warga hanya diedukasi untuk memeriksakan kesehatannya di puskesmas dan pelayanan home care 24 jam.

Selain menunggu telepon dari warga yang membutuhkan layanan kesehatan tim home care juga akan melayani perawatan pasien pasca operasi, setelah pihak rumah sakit menginformasikan ke Dinas Kesehatan
Kota Makassar yang kemudian meneruskan ke puskesmas yang terdekat dari rumah warga yang sakit.

Tentunya dengan banyaknya Akses layanan kesehatan khususnya Kota Makassar di harapkan memberikan kemudahan pada masyarakat dalam mendapatkan pelayanan kesehatan semua kalangan baik yang menengah ke atas maupun yang menengah ke bawah sehingga dapat memberikan kemudahan dalam pelayanan kesehatan sekalipun di rumah.

Kepmen PAN No.58 Tahun 2002 pengelompokan pelayanan publik menjadi tiga yaitu: pelayanan administratif, pelayanan barang dan pelayanan jasa. Pelayanan jasa didefenisikan sebagai jenis pelayanan yang diberikan oleh unit pelayanan berupa saran prasarana serta penunjangnya.Menurut Inu kencana syafiie (2003) pelayanan terdiri dari tiga unsur pokok yaitu, 1. Biaya relatif lebih rendah, 2. Waktu untuk mengerjakan relatif lebih cepat dan 3. Mutu yang diberikan relatif bagus. 
Dari segi bahasa,menurut oxford learner's, (dalam Suharsaputra 2016) inovasi adalah membuat perubahan atau memperkenalkan halhal yang baru. Menurut Rosenfeld (2002), Inovasi adalah transformasi pengetahuan kepada produk, proses dan jasa baru; tindakan menggunakan sesuatu yang baru. Inovasi pada sektor publik lebih ditekankan pada aspek perbaikan yang dihasilkan dari kegiatan inovasi tersebut.

Inovasi pelayanan membuat pelayanan public lebih baik jika diselenggarakan dengan baik pula, jangan sampai inovasi hanya mengikuti trend saja sehingga akan mati kemudian. Inovasi harus berkelanjutan sehingga inovasi dapat berubah-ubah sesuai dengan kebutuhan dan perkembangan masyarakat.

Inovasi pelayanan kesehatan membuktikan bahwa menghasilkan perubahan pelayanan kesehatan kepada masyarakat yang lebih baik. Adanya inovasi pelayanan kesehatan pada suatu institusi juga membuktikan adanya kemauan keras dari dalam organisasi kesehatan untuk berbuat lebih baik, sebab menciptakan inovasi pelayanan tidaklah mudah, organisasi yang mampu memandang diri sendiri sebagai pelayan masyarakatlah yang mampu menciptakan inovasi yang sulit untuk dirinya sendiri akan tetapi bermanfaat bagi masyarakat yang luas.

Tipologi inovasi di sektor publik menurut Halvorsen (dalam Suwarno, 2008 ) adalah sebagai berikut :

a new or improved service (pelayanan baru atau pelayanan yang diperbaiki), misalnya kesehatan dirumah.

Process innovation (inovasi proses) misalnya perubahan dalam proses penyediaan pelayanan atau produk.

\section{Administrative innovation}

(inovasi administratif), misalnya penggunaan instrumen kebijakan baru sebagai hasil dari perubahan kebijakan.

Systen innovation (inovasi sistem) adalah sistem baru atau perubahan mendasar dari sistem yang ada dengan mendirikan organisasi baru 
atau bentuk baru kerjasama dan interaksi.

Conteptual innovation (inovasi konseptual) adalah perubahan dalam outlook, seperti misalnya manajemen air terpadu atau mobility leasing

Radical change of rationality (perubahan radikal), yang dimaksud adalah pergeseran pandangan umum atau mental matriks dari pegawai instansi pemerintah

Level inovasi ini dijelaskan oleh Mulgan dan Albury berentang mulai dari incremental, radikal, sampai tranformatif (Muluk,2008).

Inovasi Incremental berarti inovasi yang terjadi untuk membawa perubahan-perubahan kecil terhadap suatu proses atau layanan yang ada.

Inovasi radikal merupakan perubahan mendasar dalam pelayanan public atau pengenalan cara-cara yang sama sekali baru dalam proses keorganisasian dan pelayanan.

Inovasi transformatif atau sistematis membawa perubahan dalam struktur angkatan kerja dan keorganisasian dan menstransformasi semua sector dan secara dramatis mengubah keorganisasian.

Menurut Sumarwan (2010), Suatu Inovasi Memiliki Karakteristik sebagai berikut:

Keunggulan relatif adalah derajat dimana suatu inovasi dianggap lebih baik/unggul dari yang pernah ada sebelumnya.

Kerumitan adalah derajat dimana inovasi dianggap sebagai suatu yang sulit untuk dipahami dan digunakan.

Kemampuan untuk diamati adalah derajat dimana hasil suatu inovasi dapat terlihat oleh orang lain.

Kompabilitas adalah derajat dimana inovasi tersebut dianggap konsisten dengan nilai-nilai yang berlaku, pengalaman masa lalu.

Kemampuan diujicobakan adalah derajat dimana suatu inovasi dapat diuji coba batas tertentu.

Proses inovasi bagi organisasi berbeda dengan proses yang terjadi secara individu. Sebagai sebuah organisasi sector public dalam mengadopsi produksi inovasi akan 
melalui tahapan sebagai berikut (Rogers 2003):

Iniatiation atau perintisan Tahapan perintisan atau fase agenda setting dan matching. Ini merupakan tahapan awal pengenalan situasi dan pemahaman permasalahan yang terjadi.

\begin{tabular}{l}
\multicolumn{3}{c}{ Implementation atau } \\
pelaksanaan Pada tahapan ini, \\
perintisan telah menghasilkan \\
keputusan untuk mencari dan \\
menerima inovasi yang dianggap dapat \\
menyelesaikan \\
organisasi.
\end{tabular}

Menurut Departemen

Kesehatan (2002), menyebutkan bahwa home care adalah pelayanan kesehatan yang berkesinambungan dan komprehensif yang diberikan kepada individu dan keluarga ditempat tinggal mereka yang bertujuan untuk meningkatkan, mempertahankan atau memulihkan kesehatan atau memaksimalkan tingkat kemandirian dan meminimalkan akibat dari penyakit.

Sedangkan menurut Neis dan McEwen (2001), menyatakan home health care adalah sistem dimana pelayanan kesehatan dan pelayanan sosial diberikan di rumah kepada orang-orang yang cacat atau orangorang yang harus tinggal di rumah karena kondisi kesehatannya.

Ada beberapa ruang lingkup home care sebagai berikut:

Memberi asuhan keperawatan secara komprehensif, Melakukan pendidikan kesehatan pada pasien dan keluarganya, Mengembangkan pemberdayaan pasien dan keluarga

Menurut Nuryandari (2004), menyebutkan ruang lingkup perawatan kesehatan di rumah (home care) juga dapat dikelompokkan sebagai berikut:

Pelayanan medik dan asuhan keperawatan, Pelayanan sosial dan upaya menciptakan lingkungan yang terapeutik, Pelayanan rehabilitasi dan terapi fisik, Pelayanan informan dan rujukan, Pendidikan, pelatihan dan penyuluhan kesehatan, Higiene dan sanitasi perorangan serta lingkungan, Pelayanan perbaikan untuk kegiatan sosial. 


\section{METODE PENELITIAN}

Penelitian ini dilakukan dan direncanakan berlansung selama 2 bulan. Lokasi Penelitian dilakukan di Dinas Kesehatan Kota Makassar, Puskesmas Panambungan, dan Puskesmas Batua.

Disertai dengan pertimbangan bahwa melakukan penelitian mengenai inovasi pelayanan publik bidang kesehatan berbasis home care adalah Untuk mengetahui pelaksanaan Home Care di Kota Makassar dan mengetahui faktor-faktor yang mempengaruhi pelaksanaan Home Care di Kota Makassar.

$$
\text { Jenis penelitian yang }
$$

digunakan dalam penelitian ini adalah penelitian kualitatifyang berusaha menjelaskan sedetil mungkin objek dan masalah penelitian berdasarkan fakta yang diperoleh dilapangan mengenai pelaksanaan inovasi home care di Kota Makassar. Tipe penelitan yang digunakan dalam penelitian adalah fenomenologi yang merupakan bentuk penelitian yang bertujuan untuk memberikan gambaran umum berbagai macam data yang dikumpul dari lapangan secara objektif bedasarkan fenomena-fenomena yang terjadi bedasarkan pengalaman hidup seseorang.

Adapun sumber data yang digunakan terbagi atas 2 yaitu data primer dengan menggunakan wawancara sejumlah orang yang berkaitan dengan pelaksanaan home care di Kota Makassar dan data sekunder dengan mengumpulkan berupa dokumen ataupun laporan tertulis yang berkaitan dengan pelaksanaan inovasi home care di Kota Makassar.

Jumlah informan pada penelitian ini sebanyak 6 orang informan yang terdiri dari Kepala Bidang Pelayanan Kesehatan Dinas Kesehatan Kota Makassar, Penanggung Jawab Home Care Puskesmas Batua, Penanggung Jawab Home CarePuskesmas Panambungan dan Masyarakat 3 orang. Dalam penelitian pengumpulan data dilakukan melalui beberapa teknik diantaranya wawancara mendalam, observasi, dan dokumentasi. 


\section{HASIL DAN PEMBAHASAN}

Dalam penelitian ini ada beberapa indikator dalam inovasi pelayanan publik bidang kesehatan berbasis home care. Untuk menilai sejauh mana inovasi pelayanan home care terlaksana di Kota Makassar.

Diantaranya adalah karakteristik inovasi pelayanan publik bidang kesehatan berbasis home care yaitu keunggulan relatif, kerumitan, dan kemampuan untuk diamati. Dan untuk mengetahui faktor-faktor yang mempengaruhi pelaksanaan inovasi pelayanan publik bidang kesehatan berbasis home care di Kota Makassar antara lain: Sumber Daya Manusia, Sarana dan Prasarana, dan Sosialisasi.

Bedasarkan hasil penelitian dan data dari informan yang telah dikumpulkan oleh peneliti maka langkah yang selanjutnya yang dilakukan adalah analisis data yang telah terkumpul. Sehingga data yang diperoleh dapat menjawab permasalahan-permasalahan yang telah dirumuskan.

Dalam melakukan analisis ini peneliti mengunakan teknik
analisisMiles dan Huberman (2012) bahwa aktifitas dalam analisis data kualitatif dilakukan secara interaktif dan berlansung secara terus menerus sampai tuntas sehingga datanya jenuh dan tidak ditemukannya lagi data baru.

Inovasi pada bidang kesehatan khususnya di Kota Makassar tentunya sangat lah penting karena berbagai fenomena yang terjadi pada layanan kesehatan yang tidak merata dalam hal pelayanan publik tentunya mengharuskan adanya peningkatan kualitas pelayanan kesehatan melalui perbaikan sarana dan prasarana serta peningkatan akses layanan kesehatan kepada masyarakat.

Tentunya inovasi home care memiliki kesamaan dengan Dokter Keluarga Dokter Keluarga melakukan kunjungan kerumah keluarga dan kesamaan lainnya terletak pada tujuan pelaksanaan, jenis pelayanan dan Biaya. Hanya saja terdapat beberapa perbedaan pada sifat pelayanan kalau home care memeriksa sesuai keluhan pasien dan bertanggung jawab hingga sembuh kalau dokter keluarga menyeluruh bukan hanya sekedar yang 
dikeluhkan pasien dan bertanggung jawab sepanjang hayatnya. Selain itu perbedaan terletak pada sasaran pelayanan kalau home care sasaran pelayanan kepada masyarakat yang membutuhkan pelayanan sesuai keluhan sedangkan Dokter Keluarga sasarannya keluarga sebagai suatu unit.

Layanan Home Care merupakan salah satu cara baru pemerintah dalam memberikan pelayanan kesehatan khususnya bagi masyarakat yang kondisinya emergency ataupun kondisi yang tidak memungkinkan untuk bisa datang ke puskesmas. Sehingga layanan ini perlu dinilai apakah merupakan sebuah cara baru dalam memberikan pelayanan kesehatan dan memberikan nilai tambah terhadap layanan sebelumnya.

Selama ini masih adanya program pemerintah yang dikeluhkan oleh masyarakat karena diangap tidak menyentuh langsung kepentingan masyarakat atau tidak memberikan manfaat yang sangat dibutuhkan oleh masyarakat luas dalam hal bidang kesehatan, terutama pada masyarakat miskin ataupun masyarakat yang memiliki penghasilan ekonomi yang rendah.

Dalam pelaksanaan ataupun prakteknya inovasi home care di Kota Makassar telah menunjukkan hasil yang baik yang dimana pemerintah selaku pembuat kebijakan ataupun program telah menjawab tantangan yang menjadi kebutuhan masyarakat pada pelayanan publik terutama dalam hal inovasi pelayanan kesehatan yang dimana kesehatan merupakan salah satu kebutuhan penting bagi masyarakat.

Hal itu sesuai dengan (Wijayanti, 2008). inovasi pada sektor publik lebih ditekankan pada aspek "perbaikan" yang dihasilkan dari kegiatan inovasi tersebut, yaitu pemerintah mampu memberikan pelayanan public secara lebih efektif, efisien, dan berkualitas, murah dan terjangkau.

Pelaksanaan Inovasi home
care di Kota Makassar secara
keseluruhan telah berjalan sesuai
harapan yang dimana Dinas Kesehatan
Kota Makassar dan seluruh Puskesmas 
yang ada di Kota Makassar Berjumlah 48 bertugas sebagai pelaksana dan penanggung jawab inovasi home care. Hal itu bisa di lihat dari jumlah pengguna di tahun 2016 berjumlah 3.379 pengguna home care. Ini menunjukkan bahwa pelaksanaan program home care ini telah memenuhi kebutuhan masyarakat dalam pelayanan kesehatan yang kiranya masih perlu perbaikan.

Dalam praktek ataupun implementasi program home care yang dibuat Pemerintah Kota Makassar tentunya harus dilihat dari beberapa hal untuk mengetahui apakah suatu program atau inovasi tersebut menjadikan sebagai alat ataupun akses dari program tersebut yang selama ini memang dibutuhkan masyarakat ataupun memenuhi kebutuhan masyarakat secara keseluruhan dalam memperoleh kesehatan yang menjadi haknya diantaranya sebagai berikut:

Keunggulan suatu inovasi merupakan aspek yang sangat penting dalam mengimplementasi kan suatu program. Bedasarkan hasil dari informan dapat di tarik kesimpulankeunggulan inovasi home care yang dimilikimulai dari biaya yang gratis, mekanisme pelaksanaanya dan pelayanannya akan memberikan ciri khas tersendiri sehingga dengan mudahnya masyarakat dapat menggunakan home care tersebut dan keunggulan tersebut dapat memberikan suatu hasil yang baik sehingga tujuan dari program home care tersebut dapat tercapai.

Hal itu sesuai dengan Suwarman (2010), suatu inovasi di anggap lebih baik atau unggul dari yang pernah ada sebelumnya di lihat dari ekonominya, kepuasan, dan lainlain. semakin besar keunggulan dirasakan semakin cepat inovasi dapat diadopsi.

Keunggulan Inovasi Home Care yang bervariasi tentunya akan memberikan dampak bagi masyarakat selaku pengguna dan diharapkan akan semakin meningkatkan minat masyarakat tentunya yang setiap tahun akan terus semakin bertambah dan pelayanan kesehatan yang semakin baik. Adapun keunggulan inovasi home care diantaranya sebagai berikut: 
Terdiri dari 3 bentuk layanan Home Care Visited, Home Care Emergency, dan Home Care Follow Up.Biaya untuk akses home care bagi masyarakat gratis dan untuk semua masyarakat tanpa melihat status sosial. Mekanisme pelayanan home care yang mudah cukup dengan call center 112 pihak dari puskesmas akan datang ke rumah dan Layanan home care 24 jam.

Kerumitan bedasarkan hasil analisis data dari informan dapat ditarik kesimpulan dalam sebuah inovasi dalam hal ini home care ada ini tak lepas dari beberapa hal dan secara umum kerumitan atau kesulitan dari program home care lebih kepada skill sumber daya manusianya yang berbeda walaupun tersedia dan kebutuhan masyarakat apabila dalam situasi tertentu sehingga tujuan dari program tersebut tidak terganggu dan dapat tercapai.

Beberapa inovasi tentu ada yang dengan mudahnya dapat dipahami ataupun digunakan ada juga yang sebaliknya semakin sulit untuk dipahami dan dimengerti maka semakin lama suatu inovasi dapat di adopsi.

Dengan kerumitan yang ada pada inovasi home care tentunya akan berpengaruh kepada masyarakat juga selaku pengguna dan inovasi home care juga tentunya harus bisa cocok pada semua situasi jika yang layanan 24 jam akan tetapi ketika masyarakat membutuhkan layanan itu pada situasi tertentu seperti pada tengah malam tapi dari pelaksana home care tidak siap karena tidak adanya sumber daya manusia tentunya akan membuat inovasi home care akan sulit. Dengan berbedanya harapan dan kenyataan pada pelaksanaan dari home care akan membuat paradigma masyarakat tentunya akan mengalami kebingungan dengan situasi tersebut.

Kemampuan untuk diamati dari suatu inovasi merupakan bagian yang sangat penting dalam menilai suatu inovasi. Bedasrkan dari hasil analisis data dari informan dapat ditarik kesimpulan bahwa dengan program home care ini dari segi praktek di lapangan atau hasil yang dapat dirasakan oleh masyarakat dapat 
terlihat secara nyata, ini menunjukkan bahwa peran masyarakat dalam praktiknya inovasi bagi masyarakat selaku pengguna layanan merupakan bagian atau penentu dalam menilai inovasi home care.

Inovasi home care tentunya telah memberikan dampak yang begitu besar kepada masyarakat khususnya dalam pelayanan kesehatan. Dan praktiknya di lapangan pun sering bisa dilihat oleh masyarakat dan ini menunjukkan telah terlaksananya inovasi home care. Dalam hal ini masyarakat tentunya memilik peran dalam menilai apakah inovasi home care dikatakan berhasil atau tidak karena inovasi ini tentunya yang menjadi sasaran adalah masyarakat itu sendiri dalam mengakses layanan kesehatan di rumah.

Dalam suatu inovasi atau program pada pengimplementasikannya di lapangan tentunya ada yang mempengaruhi selama proses berlansung. Begitupun pada inovasi home care yang terlaksana semenjak tahun 2015 berjalan hingga sekarang tentunya ada faktor-faktor yang mempengaruhi implementasi selama proses inovasi ini terlaksana diantaranya sebagai berikut: Sumber Daya Manusia merupakan elemen terpenting dalam pelaksanaan kebijakan ataupun inovasi dalam hal ini inovasi home care. Jadi sebagus apapun inovasi home care tanpa didukung oleh Sumber daya manusia yang memadai maka akan mempengaruhi pelaksanaannya di lapangan sehingga kemampuan sdmnya sendiri tentunya harus diperhatikan dengan melalui pelatihan

Menurut Sumarsono (2003), Sumber Daya Manusia menyangkut manusia yang mampu bekerja untuk memberikan jasa atau usaha kerja tersebut. Dari pernyataan tersebut sumber daya manusia yang ada pada suatu organisasi publik ataupun swasta harus mampu bekerja sesuai dengan standar yang ditentukan terutama pada sektor publik yang dihadapkan pada pelayanan publik yang tentunya harus bekerja sesuai SOP (standar operasional pelayanan). Sehingga dengan kesesuain tersebut maka 
layanan yang di dapatkan masyarakat bisa dirasakan dengan baik.

Untuk menciptakan sumber daya manusia yang memadai tentunya harapan dari seluruh organisasi publik maupun masyarakat sendiri selaku pengguna. Dalam ini home care tentunya membutuhkan sumber daya manusia tidak sedikit dengan jumlah pelaksana di seluruh kota Makassar ada 48 Puskesmas diperlukannya sumber daya manusia yang memiliki kemampuan yang sesuai selain itu dibutuhkan pengembangan ilmu ataupun keterampilan dengan melalui pelatihan yang disiapkan oleh pemerintah Kota Makassar. Adanya juga kader kesehatan yang tersebar di seluruh puskesmas Kota Makassar bedasarkan wilayah kerjanya tentunya akan menambah banyak jumlah Sumber Daya Manusia selaku pelaksana dan membantu dalam pelaksanaan inovasi home care.

Sarana dan Prasarana yang disediakan oleh pemerintah khususnya bagi Dinas Kesehatan Kota Makassar dan puskesmas se-Kota Makassar selaku pelaksana inovasi home care terdiri dari Mobil dottoro'ta, $E K G$ Telemedicine, dan $\mathrm{O} 2$ sehingga sarana dan prasarana yang disediakan sudah memadai. Sarana dan Prasarana merupakan elemen terpenting sebagai penunjang pelaksanaan inovasi dan tidak bisa dipisahkan demi tercapainya tujuan dari inovasi home care.

$$
\text { Instansi pemerintah dalam }
$$
sarana dan prasarana merupakan bagian upaya yang dilakukan di dalam pelayanan publik, karena apabila kedua hal ini tidak tersedia maka semua kegiatan yang dilakukan tidak akan dapat mencapai hasil yang diharapkan sesuai dengan rencana.

Sarana dan Prasarana yang disediakan dalam sektor pelayanan publik merupakan tanggung jawab dari pemerintah dalam ini untuk meningkatkan pelayanan publik kepada masyarakat seiring dengan kebutuhan masyarakat yang semakin banyak kebutuhan di era globalisasi saat ini. Inovasi home care merupakan salah satu program yang bertujuan perbaikan pada pelayanan kesehatan yang sejauh ini masih jauh dari harapan. Tentunya untuk mencapai 
tujuan dari home care dan pelaksanaannya berjalan sesuai harapan maka di butuhkan sarana dan prasarana penunjang.

Sosialisasi dari hasil analisis data dari informan dapat ditarik kesimpulan bahwa sosialisasi sudah sering dilakukan oleh pelaksana inovasi home care baik dari Dinas Kesehatan Kota Makassar maupun yang dibawahnya seperti Puskesmas Batua dan Puskesmas Panambungan. Adapun bentuk sosialisasi dilakukan berbagai macam seperti penyuluhan atau melakukan pertemuan dengan lintas sektor sehingga walaupun masih ada masyarakat yang belum mengetahui tetapi sosialisasi terus dilakukan.

Sosialisasi sebagai pengalaman sosial sepanjang hidup yang memungkinkan seseorang mengembangkan potensi kemanusiannya dan mempelajari polapola kebudayaan.

Sosialiasi dalam inovasi atau program home care yang baru diciptakan oleh Pemerintah Kota Makassar merupakan bagian penting dalam memperkenalkan program atau inovasi homecare kepada masyarakat. Dalam sosialisasi tentunya di butuhkan interaksi antara pemerintah dan masyarakat dalam memberikan gambaran umum kepada masyarakat mengenai home care.

$$
\text { Selain itu dalam }
$$
memperkenalkan atau memberikan pemahaman tentunya bisa dilakukan dengan cara seperti bagaimana melakukan penyuluhan di tempat kegiatan posyandu, ataupun melalui puskesmas, kemudian bisa dilakukan dengan pertemuan lintas sektor dalam membantu mengsosialisasikan kepada masyarakat.

Diharapkan dengan adanya sosialisasi home care yang dilakukan terusmenerus oleh pihak Dinas Kesehatan Kota Makassar ataupun Masing-Masing Puskesmas selaku pelakasana juga tentunya akan semakin meningkat kan pemahaman masyarakat di mulai dari mekanisme pelaksanaanya dan lain-lain. Serta inovasi home care dapat semakin bertambah jumlah penggunanya dan dijadikan suatu sistem bagi masyarakat 
yang ingin membutuhkan pelayanan kesehatan di Kota Makassar.

KESIMPULAN

Bedasarkan hasil penelitian maka penulis berkesimpulan bahwa:

Secara umum pelaksanaan home care di Kota Makassar yang berjalan sejak tahun 2015 yang dilaksanakan oleh 48 Puskesmas di seluruh wilayah Kota Makassar hingga saat ini telah terlaksana dengan baik tentunya hal ini dibuktikan dengan jumlah pengguna inovasi home care pada tahun 2016 dengan jumlah 3379 orang.

Tentunya jumlah pengguna ini yang banyak tak lepas dari kelebihan inovasi home care yang dimana kalau ada masyarakat yang sakit butuh penanganan dapat menghubungi call center 112 ataupun call center tiap puskesmas di Kota Makassar dan secara biaya gratis yang di harapakan dapat memenuhi kebutuhan masyarakat dalam memperoleh pelayanan kesehatan. Selain itu, Adapun kelebihan dari inovasi home care adalah adanya 3 bentuk pelayanan kesehatan (a) Home Care
Visited, (b) Home Care Followed Up, (3) Home Care Emergency. Akan tetapi dalam inovasi home care juga memiliki kesulitan tersendiri terkait kebutuhan masyarakat dalam kondisi tertentu seperti di tengah malam hari yang dimana tergantung kesiapan supir ataupun sumber daya manusianya. Inovasi home care ini juga dapat dilihat oleh masyarakat dan dapat dirasakan hasilnya secara nyata bagi pengguna.

Dalam Pelaksanaan inovasi home care telah diberikan dukungan oleh pemerintah berupa fasilitas seperti mobil Dottoro'ta yang merupakan mobil ambulan yang berukuran mini yang disediakan setiap 1 Puskesmas dan di dalam mobil pun ada $E K G$ Telemedicine dan O2. Selain itu adanya Sumber daya manusia selaku pelaksana yang memadai tetapi secara skill ataupun kemampuan belum tentu sama sehingga menjadi permasalahan tersendiri dalam proses pelaksanannya dan adanya kader kesehatan ada disetiap wilayah kerja puskesmas yang merupakan penghubung antara masyarakat dan pihak puskesmas jika 
ada yang membutuhkan pelayanan home care. Sosialisasi yang dilakukan oleh pihak penanggung jawab dan pelaksana home care di Kota Makassar sudah sering dilakukan dengan berbagai cara.

\section{DAFTAR PUSTAKA}

Depkes RI. 2002. Pedoman pemberantasan penyakit saluran pernafasan akut. Jakarta: Departemen Kesehatan Republik Indonesia.

Keputusan Menteri Pendayagunaan Aparatur Negara Nomor 58 Tahun 2002 Tentang Pedoman Pelaksanaan Penilaian Dan Penghargaan Citra Pelayanan Prima Sebagau Unit Pelayanan Percontohan

Khairul, Muluk. 2008. Knowledge Management: Kunci Sukses Inovasi Pemerintah Daerah. Bayumedia Publishing. Jawa Timur.

Miles, Matthew B dan A. Michael Huberman. 2012. Analisis Data Kualitatif, Buku sumber tentang metode-metode baru . Jakarta: Universitas Indonesia Press.

Neis, M.A., \& McEwen, M. 2001. Community health nursing: promoting the health of populations, (USA): W.B. Saunders Company
Nuryandari. 2004. Asuhan Keperawatan Pada Klien Dengan Gangguan Sistem Pencernaan. Edisi 1, Jakarta: Salemba Medika.

Rogers, Everett M. 2003. Diffusion Of Innovation. 5 Edition. New York: Free Press

Rosenfeld M.J. 2002.Measures of assimilation in the marriage market. Journal of marriage and family, (64), No.152, February, US: Stanford University,p 152162

Sumarsono, Sonny. 2003. Ekonomi Manajemen Sumber Daya Manusia dan Ketenagakerjaan. Yogyakarta: Graha Ilmu.

Suwarman, Ujang, Fachrodji, Achmad,dkk 2010. Pemasaran Stratejik prespektif Value-Based Marketing \& Pengukuran Kinerja. Bogor: IPB Press.

Suwarno, Yogi. 2008. Inovasi Di Sektor Publik. Jakarta: STIA LAN

Syafiie, Inu Kencana. 2003. Kepemimpinan Pemerintahan Indonesia. Bandung: Refika Aditama

Wijayanti, Irine Diana Sari. Manajemen, Yogyakarta: Mitra Cendikia Press, 2008 